\title{
EUHARISTIE ŞI CONŞTIINȚĂ MISIONARĂ ÎNTR-O SOCIETATE EUROPEANĂ POSTMODERNĂ
}

Sorin-Viorel Buş*

\begin{abstract}
The Divine Eucharist represents the center of christian liturgical life, because it represents the full communion of Christ, the world's Savior . More than that, the Eucharist offers the true value of the human being and his authentic comprehension as God's image. Our morally perverted missionary consciousness, in postmodernism, is nothing more than an emphasize of our virtue of being sons of God, adoption which was offered by our Lord, Jesus Christ, who came into the world.
\end{abstract}

Keywords: Eucharist, Liturgy, mission, missionary consciousness, postmodernism.

\section{Argument}

Din nefericire, trăim din nou, vremuri tulburi. Din nou, bătrânul continent este marcat de evenimente politice şi militare pe care noi le credeam de mult apuse sau cel puţin pentru timpurile postmoderne, imposibil de repetat. Am trăit cu toții experiența redefinirii unor granițe. Asistăm la apariţia şi reafirmarea extremismului politic, indiferent de cum s-ar numi acesta: socialism, fascism sau nazism etc. Dar, ceea ce este mai trist este apariţia şi

\footnotetext{
* PhD candidate, Babeş-Bolyai University, Cluj-Napoca, România. Cercetare finanțată prin proiectul „Minerva - Cooperare pentru cariera de elită în cercetarea doctorală şi post-doctorală", $\operatorname{cod}$ contract: POSDRU/159/1.5/S/137832, proiect cofinanţat din Fondul Social European prin Programul Operațional Sectorial Dezvoltarea Resurselor Umane 20072013.
} 
extinderea terorismului organizat sub forma unor mişcări teroriste cum ar fi grupările: ISIS, Al-Qaeda, Boko Haram etc. Legat de acest fapt, este foarte îngrijorător numărul mare de tineri europeni care se afiliează acestor grupări, părăsindu-şi țara, familia, locurile de muncă etc. De ce se aliniază aceste persoane acestor mişcări, care este farmecul acestor ideologii etc? Sunt doar câteva întrebări la care politologi, sociologi, psihologi, filosofi încearcă să ofere răspunsuri. Din nefericire, această situație devine o problemă pentru întregul continent şi în special pentru Uniunea Europeană. Avem de-a face cu o plecare a tinerilor înspre aceste grupări, cu precădere înspre gruparea ISIS, mai ales, din țările Europei de Vest, din societatea dezvoltată. Să fie acest fapt o urmare a crizei morale şi spirituale cu care se confruntă societățile dezvoltate? Nu trebuie să uităm că şi societățile mai puțin dezvoltate se confruntă cu această problemă. Aşadar, avem de-a face cu o situație care ne priveşte pe toți, situație la care teologia trebuie să ofere răspunsurile necesare. Mai mult decât atât, relativizarea valorilor morale, dezumanizarea persoanei umane sub diferite aspecte, faptul că Dumnezeu şi spiritualitatea creştină, într-o societate care a făcut experiența unor evenimente de neimaginat până la acel moment, cum au fost cele de la Auschwitz sau din gulagul rusesc, sunt scoase încet, dar susținut, din sfera publică, uitând cu totul de faptul că, ,lumina, sau sensul deplin adus omului în Hristos, este viața lui fericită fără sfârşit"1. Acest lucru ne obligă pe noi creştinii: episcopi, teologi şi simpli credincioşi să acționăm. Modul de acțiune, al creştinului autentic, nu trebuie să îmbrace forma unui prozelitism de cea mai joasă speță, nici a unui sincretism bolnăvicios, dar nici a unui extremism sau habotnicism dezbrăcat de toată dragostea şi compasiunea faţă de semenul nostru. Întreaga noastră viață, trebuie să fie un creștinism modelat de Domnul Hristos.

De la începutul istoriei şi până azi am experimentat tragismul conflictelor militare şi ca situația să fie şi mai urâtă, de-a lungul

${ }^{1}$ Dumitru Stăniloae, Iisus Hristos-Lumina lumii şi Îndumnezeitorul omului, Bucureşti, Edit. Basilica, 2014, p. 65. 
secolelor creştinii s-au măcelărit, la propriu, între ei. Ne putem întreba, fiecare dintre noi, dacă suntem sau nu în realitate creştini? Am amintit mai sus de modul de acţiune creştin. Acest mod, exemplul personal care izvorăşte dintr-o viaţă autentic creştină, într-o lume postmodernă, trebuie să fie mărturia noastră, iar mărturia creştină trebuie să devină pentru noi o misiune permanentă de propovăduire şi transfigurare a întregii creaţii. Prin venirea în lume şi naşterea din Fecioară, prin moartea şi învierea Sa, Domnul Hristos a transfigurat întregul univers şi în special pe om. În acest sens, Domnul Hristos

„,nu a adus lumii doctrine economice, proiecte de reforme sociale sau cunoaşterea tainelor de dincolo de mormânt. El a schimbat din rădăcini insăşi relația omului cu Dumnezeu, descoperindu-i acel chip al Său, care până atunci fusese intuit ca prin ceață. Buna Vestire a lui Iisus exprimă chemarea înaltă a omului şi bucuria pe care i-o dăruieşte unirea cu Creatorul. ${ }^{2}$ Mai mult, putem afirma că, ar fi greşit să înţelegem căa, din iubire pentru om, Dumnezeu-Tatăl a făcut din Fiul Său o victimă a istoriei. Nicidecum! Tot din iubire pentru om, Insuşi Fiul S-a oferit pe Sine drept victimă a istoriei”,

În societatea de azi, pe care noi o definim ca fiind postmodernă, diversitatea religioasă, mişcările de sorginte spirituale şi sincretiste cu toate variaţiile lor au luat amploare. În faţa acestei situații noi creştinii nu trebuie să acționăm ostentativ şi cu violenţă, ci în duh misionar şi după modelul lui Hristos. Dar, pentru aceasta noi trebuie să fim în Hristos, având o viață închinată Euharistiei, rugăciunii şi filantropiei creştine, deoarece ştim din Sfânta Scriptură că dragostea faţă de semeni reprezintă identitatea noastră de creştini, filantropia noastră ne certifică identitatea de ucenici ai lui Hristos şi afirmă calitatea unei vieți trăite în Dumnezeu. $O$ viaţă trăită în Hristos, este menirea creştinului să o descopere lumii contemporane,

\footnotetext{
${ }^{2}$ Alexandr Meni, Fiul Omului, trad. de Radu Părpăuță, Bucureşti, Edit. Andreas Print, 2011 , p. 77.

${ }^{3}$ IPS Bartolomeu Anania, Cartea deschisă a Împărăției, O însoțire liturgică pentru preoți şi mireni, ed a II-a, Bucureşti, Edit. I.B.M.B.O.R., 2007, p. 201.
} 
lume care este tot mai bulversată şi dezorientată din punct de vedere spiritual-moral.

\section{Euharistia misionară într-o societate europeană postmodernă}

În contemporaneitatea noastră strictă, misiunea primordială a creştinului autentic, indiferent de poziția sa socială şi de pregătirea intelectuală este de a descoperi lumii pe Hristos Domnul, care, $a$ "realizat vârful umanității, pentru că a facut-o parte a Absolutului dumnezeiesc personal",4. Noi, nu trebuie să mărturisim un Hristos transpus într-o dogmatică rigidă, în nişte concepte înțelese doar de teologia savantă. Dar, fără a ne abate de la învățătura de credință, trebuie să mărturisim pe Domnul Hristos aşa cum apare El în Sfânta Scriptură şi cum a fost trăit de Biserica euharistică de-a lungul timpului, adică un Dumnezeu iubitor şi mântuitor. Pentru a putea depune o mărturie adevărată despre Hristos Domnul, noi creştinii, trebuie să devenim ,mădulare ale Duhului Sfânt”, după expresia apostolului, să fim aşadar, purtători de har şi hristofori în sensul cel mai deplin al termenului. Afirmațiile pe care le-am făcut până aici, nu doresc să îmbrace pe viitor doar funcția unei luării de poziție, cu privire la unele aspecte esențiale cu care societatea europeană se confruntă, ci doresc, ca ele să se transforme într-un praxis duhovnicesc, într-o acțiune menită să ofere societăţii europene contemporane adevărata țintă şi valoarea supremă a propriei existențe.

$\mathrm{Cu}$ toții cunoaştem schimbările de paradigmă ce au avut loc în societatea europeană contemporană odată cu apariția umanismului şi a renaşterii şi a noilor orizonturi propuse de aceste mişcări. Ne sunt familiare frământările secolului XX, precum şi cele ale noului secol în care am intrat. Ba mai mult, s-a accentuat rolul unui dialog între teologie şi filosofie şi între teologie şi ştiință, ştiință ce cuprinde toate domeniile sale, de la medicină, astronomie şi astro-fizică şi până la

4 Dumitru Stăniloae, Chipul nemuritor al lui Dumnezeu, Bucureşti, Edit. Basilica, 2013, p. 717. 
cele mai noi descoperiri ale fizicii cuantice. Toate aceste deschideri oferă diferite oportunități de manifestare teologiei, de afirmare a bogatului său patrimoniu spiritual, dar, aceste întâlniri trebuie să ne responsabilizeze. Nu face obiectul studiului de faţă să intru mai în detaliu în ce priveşte această întâlnire a teologiei ca ştiință cu ştiința laică, deoarece s-a scris pe acest subiect volume întregi. Mă puteți întreba în schimb, la ce fel de responsabilizare a teologiei am făcut apel? O să va răspund cu o expresie biblică, expresie ce vine ca o judecată asupra noastră şi care ne atenționează de faptul că, ,din pricina voastră (noastră) este numele lui Dumnezeu blasfemiat între oameni" (Rm. 2, 24). Acestă formulare scripturistică ni se adresează tuturora, atât epicopilor, teologilor, erudiților din domeniul teologic cât şi creştinilor mireni. Nouă, teologilor, ne revine sarcina de a-L descoperi pe Hristos Domnul prin intermediul teologiei ca ştiință, de a-L propovădui pe Mântuitorul Hristos pe înțelesul oamenilor pe deo parte, pe de altă parte, avem obligația de a predica pe Domnul Hristos şi creştinismul prin faptă. De puțin timp s-au încheiat dezbaterile din presa scrisă şi audio-vizuală şi de pe diferite forumuri de discuții cu privire la ora de religie şi dacă am fost atenți, am putut observa cât de puține lucruri cunosc unii dintre semenii noştri despre Mântuitorul Hristos şi despre mântuitoarea Sa venire în lume. Habar nu au unii dintre ei despre putința mântuirii, despre această minunată lucrare, aceea de a fi mort cu trupul dar viu în Hristos, cu sufletul. Ne putem întreba, unde am fost noi creştinii de nu am reuşit să îl arătăm, să îl facem străveziu, cu adevărat, pe Domnul Hristos, societății în care trăim. Misiunea primordială a creştinului, indiferent de poziția socială şi de pregătirea intelectuală este de prezenta lumii pe Domnul Hristos şi învăţătura Sa mântuitoare, atât prin cuvânt dar mai ales prin faptă, deoarece ştim cu toții că simpla rostire a numelui lui Dumnezeu, fără faptele credinței noastre nu ajută la nimic.

În teologie vorbim despre eclesiologia euharistică, vorbim despre eshatologia euharistică şi exemplele pot continua. Ne punem întrebarea de ce pedalăm atât de mult pe Euharistie şi răspunsul este dat de faptul că Euharistia certifică creştinătatea noastră autentică. 
Biserica, scria un mare teolog ortodox, „nu este organizație, ci este poporul nou al lui Dumnezeu, Biserica nu este religie de cult, ci este Liturghia care cuprinde în sine intreaga creație a lui Dumnezeu"s. Noi, atunci suntem cu adevărat creştini când ne apropiem de potir şi mai ales atunci când o facem cu vrednicie, de aceea, „Trupul şi Sângele Domnului primite cu vrednicie sunt doctoria cea mai eficace, precum celor ce nu le primesc cu vrednicie le este spre osândă şi spre imbolnăvire”. Altfel spus, „Euharistia e coextensivă istoriei mântuirii: toată istoria mântuirii e prezentă în Euharistie şi Euharistia e prezentă în toată istoria mântuirii. Aşa cum, într-o dimineață senină, se vede reflectată toată bolta cerului, tot astfel în Euharistie se oglindeşte întreg arcul istoriei mântuirii"' decât atât, "din monumentele cele mai vechi ale literaturii bisericeşti" apare evident faptul că de la început centrul cultului creştin a fost dumnezeiasca Euharistie din ziua Domnului, care reprezenta centrul vieții sacramentale şi al întregii veți a membrilor Bisericii ${ }^{8}$. Observăm aşadar, cum Euharistia devine cale şi totodată țință. Euharistia comportă în sine şi acest aspect de mijloc sau cale în unirea cu Domnul Hristos, deoarece ea se prezintă şi ca un suport al nostru în drumul spre mântuire. Euharistia reprezintă şi ținta noastră supremă de împărtăşire cu Hristos Domnul. Toate strădaniile noastre de mântuire, tot exercitiiul ascetic este încununat prin primirea lui Hristos Domul sub chipul pânii şi a vinului prin împărtăşanie. Mai sus aminteam despre eclesiologia euharistică şi despre eshatologia

5 Alexander Schmemann, Euharistia: Taina Impărăţiei, trad. de Boris Răduleanu, Bucureşti, Edit. Sophia, 2012, p. 290.

6 Dumitru Stăniloae, Spiritualitate şi Comuniune în Liturghia Ortodoxă, Bucureşti, Edit. I.B.M.B.O.R., 2004, p. 540.

7 Raniero Cantalamessa, Euharistia: sfințirea noastră, trad. de Monica Broşteanu, Bucureşti, Edit. Arhiepiscopiei Romano-Catolice, 2000, p. 4.

${ }^{8}$ Nenad Miloşevici, Dumnezeiasca Euharistie- centrul cultului în Ortodoxie. Legătura indisolubilă a sfintelor Taine cu Dumnezeiasca Euharistie, trad. de Ioan Ică sr., Sibiu, Edit. Deisis, 2012, p. 9. 
euharistică, pentru ca în acest studiu, personal, să vorbesc despre Euharistia misionară.

Dumnezeiasca Euharistie reprezintă taina prin excelență a Bisericii, deoarece îl cuprinde pe Domnul Hristos întreg în dumnezeire şi cu omenitatea transfigurată şi trecut prin moarte şi înviere. Astfel, „Euharistia uneşte sufletele şi evenimentele prin intermediul timpului şi spațiului. Ea nu este doar un memorial al trecutului, ci şi unul al viitorului, când va veni Hristos întru slava $s a^{\text {"9 }}$. Aşa stând lucrurile, Euharistia comportă în sine şi un accentuat aspect misionar sau altfel spus, misiunea noastră de a ne transfigura propria existență şi de a transfigura întreaga creație este cuprinsă în Euharistie, avându-l ca exemplu pe Însuşi Domnul Hristos care a fost misionarul suprem al întregii creații. În societatea europeană contemporană parcă toate valorile sunt bulversate, nu este domeniu de acțiune care să nu fie supus pervertirii morale. Într-o atare situație, misiunea creştinului poate fi asemănată unui adevărat exerciţiu ascetic, comportând în ea un pronunțat caracter soteriologic. Pentru a ilustra mai bine ceea ce doresc să afirm, dau ca exemplu societatea românească, societate marcată de un profund flagel al corupției de orice fel şi din păcate simțit la orice nivel. Multe dintre persoanele implicate în acest proces al corupției cercetează biserica, se mărturisesc, se cuminecă şi actele de evlavie creştină, săvârşite de aceste persoane, pot continua. Oare acele persoane sunt cu adevărat creştine, se împărtăşesc ele cu adevărat de Hristos? Un răspuns tranşant nu pot oferi, nici nu doresc să judec pe nimeni, doresc doar să atrag atenția asupra a ceea ce înseamnă a fi cu adevărat creştin.

Sfânta Scriptură, în cartea Faptele Apostolilor, îi numeşte pe creștini sfinți, iar expresia liturgică, „sfintele, vouă, sfinților!”10, nu

9 Tomas Spidlik, Euharistia, leac pentru nemurire, trad. de Dominica Gotea,
Târgu Lăpuş, Edit. Gutenberg, 2006, p. 71 .
10 Pentru această expresie liturgică, am optat pentru traducerea şi diortosirea
realizată de Părintele Bartolomeu Anania, Mitropolitul Clujului, deoarece, în
contextul teologic dat de textul prezent, formula tradusă de Părintele
Bartolomeu Anania redă cu consistență mesajul teologic transmis de studiul 
mărturiseşte nimic altceva decât cetățenia noastră de sfinți, primită la Botez, pecetluită cu Taina Mirungerii şi desăvârşită prin primirea Dumnezeieştii Euharistii. Suntem chemați la sfințenie în dualitatea făpturii noastre, nu doar trupul sau sufletul, ci împreună şi într-o sinergie ajutați de harul dumnezeiesc necreat, să ne lucrăm propria mântuire. Este firesc, ca noi creştinii, dacă Domnul Hristos este sfânt şi ne cuminecăm din potir, unde este Sfințenia desăvârşită, să purtăm numele de sfinți. Din cauza lipsei de spațiu nu voi enumera toate problemele spiritual-morale cu care se confruntă bătrânul continent, ci, mă voi mulțumi cu a afirma faptul că în societatea europeană de azi se simte cel mai acut lipsa unei propovăduiri şi trăiri autentice a creştinismului.

Lipsa trăirii autentice a creştinismului şi pervertirea morală a societății europene sunt date de îndepărtarea şi de lipsa de înțelegere autentică a Euharistiei. Prin Euharistia misionară, ca parte integrantă a teologiei euharistice, într-o Europă tot mai desacralizată, creştinul trebuie să mărturisească Viaţa şi Împărăția lui Dumnezeu, Impărăţie ce ne-a fost dată odată cu venirea lui Iisus în lume şi care este mereu actuală. Astfel că, ,în Euharistie e descoperită impărăția lui Dumnezeu, pregustată hic et nunc" "11. Faptul că am uitat de ceea ce înseamnă cu adevărat Dumnezeiasca Euharistie, faptul că am pierdut sensul teologiei euharistice, ba mai mult, am derapat într-un clericalism exacerbat, am accentuat discrepanța dintre preoți şi mireni, când de fapt în teologia părinţilor lucrurile stau altfel, faptul că ne îmbrăcăm într-un misticism fals şi punem mai mult preț pe un simbolism neautentic creştin a făcut ca misiunea noastră să fie una obtuză şi de multe ori lipsită de substanță. Nu pot înțelege cum ne putem apropia de potir şi noi îl urâm pe aproapele nostru, nu pot înțelege cum putem să ne apropiem de potir şi să nu simţim câtă suferință fizică şi existenţială există în lume, nu pot înţelege cum ne putem împărtăşi de Hristos Domnul care este viaţa veşnică şi noi să

prezent. Rămân la poziția că, această traducere, este cea mai bună pentru a exprima identitatea şi numele de sfânt, primit prin Botez, de către creştini.

${ }^{11}$ Gheorghe Ispas, Euharistia- Taina unității Bisericii. Aspecte teologice şi practice, Bucureşti, Edit. Basilica, 2008, p. 119. 
nu simțim compasiune față de fratele care se află în necazuri. Dacă am reflecta la Dumnezeiasca Euharistie atunci când o primim, Domnul Hristos din potir ne-ar face atenți la toate lucrurile acestea. Din păcate, suntem grăbiţi şi în baza unui formalism şi a unor cutume, ne cuminecăm fără a reflecta la ce există în potir şi astfel într-un fel, devenim furi şi tâlhari de cele sfinte. Euharistia misionară ne dezvăluie ce înseamnă liturghia de după liturghie, precum şi modul împlinirii acesteia. Acest lucru se datorează faptului că cel cu care ne împărtăşim este Hristos Domnul, Viața lumii şi Mântuitorul acesteia, deoarece, „Iisus, inviind, a restabilit, prin restaurarea unui nou conținut de viață, timpul plin. Mai bine-zis, l-a dus la starea de desăvârş̧ire spre care tindea... De aici rezultă că noi, îmbrăcați în timpul nostru, avem o capacitate de-a ne apropia de sfera în care Se află Iisus inviat" "12. Aceasta este în esență misiunea creştinului într-o societate multiculturală şi pluriconfesională cum este societatea europeană de astăzi, aceea de a-l descoperi pe Hristos lumii aşa cum El ni s-a revelat şi a fost experiat şi trăit de către sfinți.

\section{Conştiință misionară într-o societate europeană postmodernă}

Vorbind la modul general despre misiunea creştină, afirmăm că aceasta îşi are,

„temeiul său adânc şi punctul de plecare în insăş̧i comuniunea veşnică a Sfintei Treimi, în mişcarea iubirii Tatălui către Fiul in Duhul Sfânt, şi prin Acesta, către intreaga lume. Astfel, misiunea este „,participare” la trimiterea Fiului (In. 20, 21-23) şi a Duhului Sfânt (In. 14, 26) in lume Care revelează viața de comuniune a lui Dumnezeu pentru a ne face părtaşi la ea"13.

12 Dumitru Stăniloae, Iisus Hristos sau Restaurarea omului, Bucureşti, Edit. Basilica, 2013, p. 463.

${ }^{13}$ Ion Bria, Curs de teologie şi practică misionară ortodoxă, Geneva, 1982, p. 3. 
O altă definiție care surprinde caracterul trinitar şi teologic al misiunii creştine este cea care ne spune că misiunea creştină reprezintă, ,trimiterea Bisericii în lume în vederea universalizării Evangheliei şi a integrării oamenilor în Împărăția lui Dumnezeu, intemeiată prin lucrarea mântuitoare a lui Iisus Hristos, inaugurată ca anticipare a ei în Biserică prin Pogorârea Duhului Sfânt, Impărătie care se va manifesta în plenitudinea ei la a doua venire a lui Hristos intru slavăa"l4. Din aceste frumoase definiții teologice, înțelegem faptul că misiunea creștină are la bază însăşi Sfânta Treime şi mai precis, trimiterea Fiului şi Duhului Sfânt în lume de către Tatăl, misiune pe care Mântuitorul Hristos a dat-o şi apostolilor şi implicit ne-a dat-o şi nouă. Pe tema misiunii creştine în lumea contemporană a curs enorm de multă cerneală, misiologia fiind una dintre discipline teologice ce au prins teren în ultimul timp, cel puțin din perspectiva materialului bogat pe care îl avem la dispoziție. Este foarte frumos şi plăcut urechii şi intelectului atunci când prezinţi aşa de frumos creştinismul în paginile unor tratate, problema se pune atunci când noi, prin viaţa noastră, trebuie să îl mărturisim pe Domnul Hristos. Mărturisim prin scris şi prin viu grai teologia părinților, cu toate acestea mesajul nostru nu se face suficient de auzit.

În acest studiu, atât cât spațiul îmi permite, doresc să afirm faptul că, pentru ca misiunea să fie una autentic creștină, este necesar să avem dezvoltată o conştiință misionară. Altfel spus, după expresia părintelui Iustin Popovici avem nevoie de o hristo-gândire sau în cazul nostru de o hristo-conştiință şi prin cele afirmate până acum, din nou ne întoarcem la problema trăirii autentice a creştinismului. La o primă analiză, expresia conştiință misionară, poate frapa, dar dacă reflectăm mai în dataliu observăm faptul că în ea se cuprind caracteristicile şi coordonatele unei vieți trăite în Hristos, după expresia lui Nicolae Cabasila. Problemele de ordin moral şi existențial, cuplate cu cele de ordin social şi economic cu care se

${ }^{14}$ Valer Bel, Misiunea Bisericii în lumea contemporană, Cluj-Napoca, Edit. Renaşterea, 2010, p. 21. 
confruntă Europa sunt foarte multe şi cauzele lor sunt profunde. Din nefericire şi creştinii au contribuit la această situaţie prin persiflarea propriei credințe.

Creştinii timpului nostru, mai mult ca niciodată trebuie să impresioneze prin faptele lor duhovniceşti, fapte care nu mărturisesc nimic altceva decât viața în Hristos pe care o trăim sau nu. Schimbările ce se petrec în societatea europeană le cunoaştem cu toții, ba mai mult, le discutăm sub diferite forme şi din perspective diferite, cu toate acestea înstrăinarea faţă de Hristos se accentuează. Legat de toate implicațiile alienării spirituale pe care le observăm derulându-se sub ochii noştri, conştiința misionară a creştinului contemporan ne spune că este nevoie de o reîncreştinare a societăţii în care trăim. Intrebarea esențială care se pune este următoarea: care este modul cel mai eficace pentru a se putea realiza acest deziderat? Conştiinţa noastră de creştini ne mărturiseşte că prima schimbare a lumii vine cu propria noastră transfigurare, conform principiului scripturistic, ,doctore vindecă-te pe tine însuți”. Dar cum putem realiza propria noastră transfigurare mântuitoare, când de fapt, în multe momente, noi săvârşim actele mântuitoare în baza unor automatisme şi cutume? Mai mult decât atât, conştiinţa misionară a creştinului autentic mărturiseşte faptul că propovăduirea mesajului hristic nu reprezintă un prozelistism ce are ca scop doar atragerea unor persoane înspre credința pe care o mărturisim, ci presupune o dimensiune specifică a credinței creştine.

Creştinul, nu face misiune doar de dragul de a face misiune, în primul rând, noi trebuie să îl trăim şi să îl propovăduim pe Hristos Domnul în mod autentic, aşa cum 1-au trăit şi propovăduit primii creştini. Indiferent de timpul liturgic în care ne aflăm, cu toții observăm faptul că, preocupați fiind cu activitățile cotidiene sau pur şi simplu din indiferenţă uităm cu totul de Dumnezeu. Conştientizăm la o analiză atentă faptul că, Domnul Hristos, Izvorul existenței nostre este trecut pe planul secund al preocupărilor personale. În realitate însă, raportul ar trebui să fie invers, Domnul Hristos şi trăirea Sa în mod deplin şi autentic, după modelul creştinismului 
primar, ar trebui să ocupe poziția fruntaşă în sfera activităților noastre şi noi să ne plasăm pe locul secund. Conştiința misionară azi, ne atenţionează asupra unui aspect foarte important şi anume, acela de a fi, pe de-o parte profeți, prin trăirea autentică, deplină şi euharistică a propriului creştinism, pentru lumea în care trăim, iar pe de altă parte, de a fi apostoli ai lui Hristos în societatea în care trăim prin intermediul exemplului personal şi al trăirii creştinismului în duhul creştinismului primar şi al părinților bisericii.

\section{În loc de concluzii}

În virtutea botezului primit, misiunea creştinului în societatea de azi a bătrânului continent, trebuie să se realizeze după modelul şi în duhul lui Hristos Domnul. Conştiința noastră de creştini ne dictează faptul că predicarea creştinismului trebuie să se realizeze în duhul iubirii fraterne şi a comuniunii euharistice. Mai mult ca oricând, acum, când continentul trece prin noi frământări economicosociale, spirituale şi politice, acțiunea creştinului trebuie să fie una discretă dar sinceră, misiunea noastră trebuie să fie una articulată şi bine angrenată în societate dar plină de dragostea Mântuitorului Hristos, ba mai mult, acțiunea noastră trebuie să fie una animatoare şi transfiguratoare pentru întreaga creație.

\section{Bibliografie:}

\section{A. Izvoare:}

1. Biblia sau Sfânta Scriptură, versiunea Bartolomeu Valeriu Anania, Bucureşti, Ed. Institutului Biblic şi de Misiune al Bisericii Ortodoxe Române, 2001.

\section{B. Bibliografie selectivă:}

2. Anania, IPS Bartolomeu, Cartea deschisă a Împărăției, O însoțire liturgică pentru preoți şi mireni, ed a II-a, Bucureşti, Edit. Institutului Biblic şi de Misiune al Bisericii Ortodoxe Române, 2007. 
3. Bel, Valer, Misiunea Bisericii în lumea contemporană, Cluj-Napoca, Edit. Renaşterea, 2010.

4. Bria, Ion, Curs de teologie şi practică misionară ortodoxă, Geneva, 1982.

5. Cantalamessa, Raniero, Euharistia: sfințirea noastră, trad. de Monica Broşteanu, Bucureşti, Edit. Arhiepiscopiei Romano-Catolice, 2000.

6. Ispas, Gheorghe, Euharistia- Taina unității Bisericii. Aspecte teologice şi practice, Bucureşti, Edit. Basilica, 2008.

7. Meni, Alexandr, Fiul Omului, trad. de Radu Părpăuță, Bucureşti, Edit. Andreas Print, 2011.

8. Miloşevici, Nenad, Dumnezeiasca Euharistie- centrul cultului în Ortodoxie. Legătura indisolubilă a sfintelor Taine cu Dumnezeiasca Euharistie, trad. de Ioan Ică sr., Sibiu, Edit. Deisis, 2012.

9. Schmemann, Alexander, Euharistia: Taina Impărăției, trad. de Boris Răduleanu, Bucureşti, Edit. Sophia, 2012.

10. Spidlik, Tomas, Euharistia, leac pentru nemurire, trad. de Dominica Gotea, Edit. Gutenberg, Târgu Lăpuş, 2006.

11. Stăniloae, Dumitru, Chipul nemuritor al lui Dumnezeu, Bucureşti, Edit. Basilica, 2013.

12. Idem, Iisus Hristos- Lumina lumii şi Îndumnezeitorul omului, Bucureşti, Edit. Basilica, 2014.

13. Idem, Iisus Hristos sau Restaurarea omului, Bucureşti, Edit. Basilica, 2013.

14. Idem, Spiritualitate şi Comuniune în Liturghia Ortodoxă, Bucureşti, Edit. Institutului Biblic şi de Misiune al Bisericii Ortodoxe Române, 2004. 